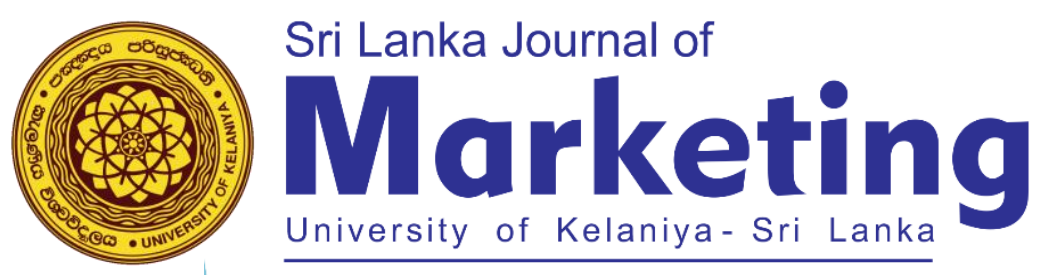

\title{
The Impact of 'on the Job Training' on Employee Performance: A Study of Production Assistants in Noritake Lanka (Pvt) Limited, Mathale, Sri Lanka
}

\begin{tabular}{|c|}
\hline Nawarathna K. J. N. M. D. V. \\
Faculty of Humanities and Social Sciences, Open University of Sri Lanka \\
dinushavihangani93@gmail.com \\
Abeykoon M.W. M. \\
Small Enterprise Development Division, District Secretariat, Gampaha \\
maheshasjp163@gmail.com \\
Harshani M. D. R. \\
Department of Human Resource Management, University of Kelaniya, Sri Lanka \\
rasikaharshani27@gmail.com
\end{tabular}

\section{ABSTRACT}

In present business world a lot of entities tend to conduct training programs to the employees and expecting high level of performance from the employees. Hence the different kinds of training methods are used by the manufacturing sectors to train workforce. Although there are number of researches conducted in assessing the impact of training programs of manufacturing industry in other countries in Sri Lankan context research findings in this regard is limited. Therefore, the objective of the current study was to assess the impact of 'employee on the Job Training on the performance of production assistants in Noritake Lanka (Pvt) Ltd. Matale, Sri Lanka

The independent variable and the dependent variable of this study were the level of on-the job training and the employee performance respectively. The reliability of the instruments was tested by using Cornbrash's Alpha coefficient. The type of this study is hypothesis testing ant it was conducted in the natural setting with the minimum interference of the researcher. The study is a cross-sectional in time and the primary data were collected by using random sampling technique and sample size was 100 production assistant employees who are working in Noritake Lanka (Pvt) Ltd in Matale District. The unit analysis was at individual level. Data was collected through a structured questionnaire. The offline method was use to gather the data and the primary data set was used. The correlation and regressions methods were performed to test hypotheses and analyzed data.

Finding revealed that on-the-job training has a significant impact on employee performance. Correlation analysis shows that on-the-job training has a strong positive relationship on employee performance. As a significant factor, this would mean that it is very significant to pay a high attention regarding the onthe-job training methods, because it directly affects to the performance of the employees in addition to 
that proper and well-structured on-the-job training are required to meet with the desired outcomes of the organization. Plenty of benefits can be obtained from on-the-job training method for the both employees and the organization.

Keywords: Employee on the Job Training, Employee Performance, Production Assistants

\section{INTRODUCTION}

In today's dynamic environment the stipulate for professional and highly skillful workforce are necessary for every organization to perform well in this environment (Yaqoob2011). Training methods are very significant for any kind of business organization to enhance knowledge, skills and attitudes of the existing workforce of the organization. When considering about the manufacturing sector the training methods play a vital role, especially about the non-executive workers. Providing training to the non-executive workers is very significant, because these workers mainly engage with the day to day operations of the organization (Hamidum 2003). According to Mawita (2000) the training can be described as a systematic process of developing knowledge, skills, attitudes and technology needed to assist a person to perform in his present job. It helps the individual to match up to the requirements of their jobs (Mawita, 2000). The different kinds of training methods are conducted by the organization. These training methods can be broadly divided in to two categories namely on the job training and off the job training. By using training methods, the management of the organization expects to increase the capability and productivity of the workers to achieve ultimate goals and objectives of the organization within the existing workforce. The on the job training is used during the workers engage in their duties, whereas off the job training are conducted outside from their job duties such as lectures, role plays, computer aided instructions etc. If the workers' performance does not enhance after the training, it will become wastage of both money and time of the entire organization. In this rapidly changing world, the management and achievement of employee's performance is gradually become more challenging and multi-tasking in an organization. In many instances poor performance arises because of the design of the job (Yaqoob, 2011). Employees will be motivated to perform well in jobs that offer variety, a challenge, responsibility, and an opportunity for personal growth. In the absence of these characteristics, less than optimum performance can be expected (Albers, Cohen, and Mohrman 1995; Cranny, Smith, and Stone 1992). In present business world a lot of entities tend to conduct training programs to the employees and expecting high level of performance from the working employees. The different kinds of training methods are used by the manufacturing sectors to train their workforce. Basically the training is required when there is a gap between current employees' knowledge, skills and attitudes with the standard and expected level of knowledge, skills and attitudes. Training is one of concepts which have made impact on employee performance. By referencing the 
previous scholars researches on different western and eastern countries says that there is a positive impact on training and performance of the employees. The training methods may have some considerable impact on the employee performance. The employee performance is not a single concept and it is impacted by different components. Most of the training methods tend to be highly concerned on the employee performance and survival of their own country with increment of the global competition. Because of the performance issues companies and organizations were unable to survive in their industries. In present business world a lot of entities tend to conduct training programs to the employees and expecting high level of performance from the working employees. The different kinds of training methods are used by the manufacturing sectors to train their workforce. Basically the training is required when there is a gap between current employees' knowledge, skills and attitudes with the standard and expected level of knowledge, skills and attitudes. Training is one of concepts which have made impact on employee performance. By referencing the previous scholars' researches on different western and eastern countries says that there is a positive impact on training and performance of the employees. The training methods may have some considerable impact on the employee performance. The employee performance is not a single concept and it is impacted by different components. Most of the training methods tend to be highly concerned on the employee performance.

The factory Noritake Lanka (Pvt) Ltd in Matale District started its operations in 1972 just with 150 workforces and as at today workforce stands with 1200 skilled workers. Most of the workers, supervisors and managers of the factory are trained in Japan in their relevant fields. Noritake factory in Matale is one of the largest production facilities in the world to make high quality tableware under the brand "Noritake". This organization has 38 departments. Most of department are directly participated for the manufacturing process in organization such as preparation, moulding forming, casting, roasting, glazing, loading, white ware inspection, fine casual china, decoration, decoration inspection, decoration roasting, printing, packing, etc The purpose of this research is to identify the impact of the on-the job training methods on enhancing the performance of the workers.

\section{PROBLEM STATEMENT}

In present business world a lot of entities tend to conduct training programs to the employees and expecting high level of performance from the working employees. The different kinds of training methods are used by the manufacturing sectors to train their workforce. Basically the training is required when there is a gap between current employees' knowledge, skills and attitudes with the standard and expected level of knowledge, skills and attitudes. Training is one of the concept which has made impact on employee performance. And most of the organizations, train their employees expecting a high performance. By studying the previous scholars researches on different countries, there is a positive impact on training and performance of the employees. But in Sri Lankan context research on this regard is very limited. And even there are limited studies done on the impact of training on employee 
performance in manufacturing firms. This study was conducted only to check whether the on the job training method affect the performance, as in this particular organization most of the time employees are trained based on the on the job training method. Therefore, this research study was conducted basically to assess the impact of on-the job training methods to the performance of production assistant in Noritake Lanka Porcelain (Pvt) Ltd in Matale district.

\section{LITERATURE REVIEW}

Performance is a major multidimensional construct aimed to achieve results and has a strong link to strategic goals of the organization (Mawita, 2000). As the Mawita (2000), explains that performance is the key element to achieve the goals of the organization. However, the questions arise that how an employee can work more effectively and efficiently to increase the growth and the productivity of the organization (Yaqoob 2011). Further it is the outcome or contribution of employees to make them attain the goals (Nassazi, 2013). The importance of training on the employee performance, through accelerating the learning process, is mentioned in many researches (e.g. McGill and Slocum, 1993; Ulrichet al., 1993; Nonaka and Takeuchi, 1995; DiBella et al., 1996).

As a key element training provides the ability of working in any sort of employee, even in nonprofessional and new employees, it pushes up the abilities of professional to a higher stage from where they currently stand.

According to Aslam (2014), training programs are effective for employee performance keeping the arrangement and adoption of training as a planned procedure to make the performance more effective. Recent studies mentioned that training is an essential element for sustainable competitive advantage and survival in the $21^{\text {st }}$ century as it is the process of providing employees with specific skills or helping them to correct deficiencies in their performance (Hamidum, 2003).

According to the Armstrong (2000), "Training is systematic development of the knowledge, skills and attitudes required by an individual to perform adequately a given task or job. The term 'training' indicates the process involved in improving the aptitudes, skills and abilities of the employees to perform specific jobs" (Kogan2001). Training is considered as the process of improving the existing skills, knowledge, exposure, and abilities in an individual (Mehwish, 2011)

According to Aswathappa (2000), Effective training methods aimed at improving the employees' performance. Further training not only develops the capabilities of the employee but sharpen their thinking ability and creativity in order to take better decision in time and in more productive manner (David, 2013). According to Rowden \& Conine (2013), well trained employees become more confident in their work, which results in fewer mistakes, reduced rework and thus, higher productivity. 
Training is essential not only to increase productivity but also to motivate and inspire workers by letting them know how important their jobs are and giving them all the information they need to perform those jobs (Anonymous 1998). On-the- job training is another delivery approach of training, which takes place at normal workplace and makes the job itself part of the instruction given and a means of acquiring practical skills (Trang2014). Based on previous research, workers in low -paid jobs have less opportunity for on-the-job training as compared to workers in higher-paid jobs (Isik, Gordon, Karlene and James, 2008). Consistent with Lin and Tremblay (2003), research showed that workers who are higher educated are more likely to receive on-the-job training.

According to literature common on-the job training methods can be identified as job rotation, job instruction, and apprenticeship and coaching.

\subsection{Job Rotation}

Job Rotation is a system which is capable of augmenting employees' motivation and commitment within an organization and make wider observations as well. It brings an enlargement in work rate of human resources, tries to get better firm execution, individual mortal levels of multi-experienced employees, well obtainable capabilities and as well as new perspectives for attitude, deliberation, potentialities and hidden talent of employees (Khan,Raslia,Rosman, 2014). Further according to Delpasand (2011), job rotation is defined as falls into the greater as compared to before individual knowledge, familiarity and tiredness.

Job Rotation has been used to implement the increasing employee momentum and taking active part in job within the organization, which are incredibly vital for valuable performance (Zeira, 1974). Job Rotation establishes a successful routine of increasing talents, enthusiasm, encouragement and motivation of an employee within the organization (Friedrich, Kabst, Weber, \& Rodehuth,1998). Jaime (2000), posited that job rotation promotes psychological and physical health of employees through creating positive attitudes on employees, facilitating their health and increasing the variety of work through reduction of boredom to work, seeing things in a new perspective, decreasing in physically demanding portfolios and having self-motivation towards their positions in organizations.

\subsection{Job instruction}

Job instruction training is a structured approach to training, which requires trainees to proceed through a series of steps in sequential pattern. (Kulkarni,2013). The instructor or supervisor prepares a job breakdown on the job, while watching an experienced worker perform each step of the job. Job instruction technique consists of four steps, preparation, present, try out and follow up (Alipour and Mehrdad, 2009) 


\subsection{Apprenticeship}

Apprenticeship is one of the oldest forms of training which is designed to provide planned, practical instruction over a significant time span. Apprenticeship was the major approach to learning a craft. The apprentice worked with a recognized master craft person (Namara, 2000).

\subsection{Coaching}

Coaching is the process of one-on-one guidance and instruction to improve knowledge, skills and work performance. Coaching is becoming a very popular means of development, and often includes working one-on-one with the learner to conduct a needs assessment, set major goals to accomplish, develop an action plan, and support the learner to accomplish the plan. The learner drives these activities and the coach provides continuing feedback and support. Usually coaching is directed at employees with performance deficiencies, but also used as a motivational tool for those performing well. Coaching methods solve precise problems such as communication, time management and social skills. Executive coaching generally takes place on a monthly basis and continues over a period of several years. Often, coaches are brought in where there is a change in the structure of the company, when a team or individual is not performing well or where new skills are required. Coaching assumes that you are fine but could be even better (Kirwan,2000). Implementing training programs as a solution to covering performance issues such as filling the gap between the standard and the actual performance is an effective way of improving employee performance (Swart et al., 2005). According to Wright and Geroy (2001), employee competencies changes through effective training programs. It no to only improves the overall performance of the employees to effectively perform the current job but also enhance the knowledge, skills an attitude of the workers necessary for the future job, thus contributing to superior organizational performance. Besides, Eisenbergeret al. (1986) stated that workers feel more committed to the firm, when they feel organizational commitment towards them and thus show higher performance. Bartel (1994), reports that there is a positive correlation between effective training program and employee productivity, however to make it possible, (Swart et al., 2005), it is the responsibility of the managers to identify the factors that hinders training program effectiveness and should take necessary measures to neutralize their effect on employee performance.

\section{CONCEPTUAL FRAMEWORK}

This research model is prepared to make an insight in to the impact of on-the job training methods to employees' performance Noritake Lanka Porcelain (Pvt) in Matale District. The proposed frame work of the independent and dependent variables has been adopted from the Colarelli and Montei , 1996. 
Figure 1: Conceptual Framework

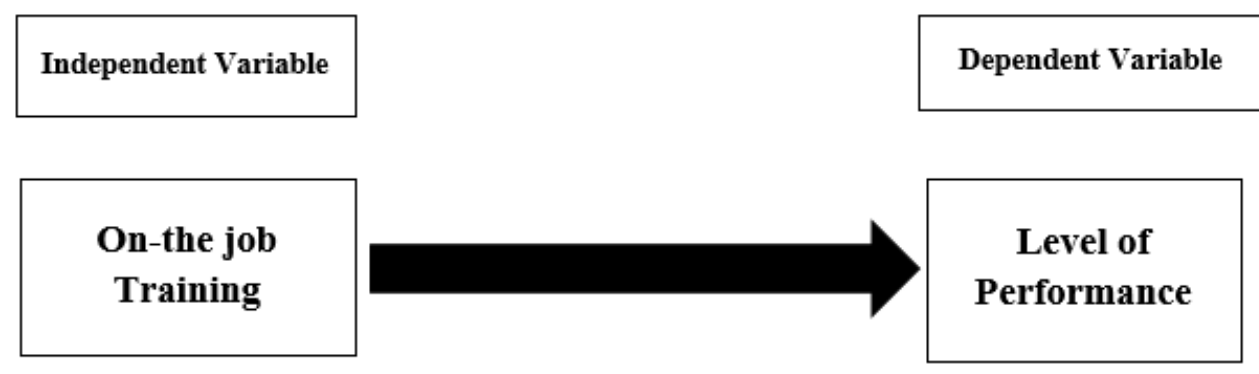

Source: Colarelli \& Montei, 1996

The dependent variable of this study is the employee performance and the independent variable is Level of on-the job Training. The basic objective of this research is to find the impact of on-the job training methods to non-executive workers' performance in Noritake Lanka Porcelain (Pvt) in Malate district.

\subsection{Dependent Variable}

Employee performance is defined as the outcome or contribution of employees to make them attain goals (Nassazi, 2013) while performance may be used to define what an organization has accomplished with respect to the process, results, relevance and success Uganda National Development Program (1995). Afshan, (2012) define performance as the achievement of specific tasks measured against predetermined or identified standards of accuracy, completeness, cost and speed. Employee performance can be manifested in improvement in production, easiness in using the new technology, highly motivated workers.

Employee's performance is higher in happy and satisfied workers and the management easy to motivate high performance to attain firm's targets. Kinieki and Kreitner,(2007).An organization that gives worth to knowledge as a source of gaining competitive edge than competitors, should build up system that ensure constant learning, and on the effective way of doing so is training Leonard- Barton, (1992) . Well trained workforce is more capable of achieving performance targets and gaining competitive advantage in the market (Imran, 2013).

\subsection{Independent Variable}

According to the Armstrong, (2000) "Training is systematic development of the knowledge, skills and attitudes required by an individual to perform adequately a given task or job" Kogan, (2001). The term 'training' indicates the process involved in improving the aptitudes, skills and abilities of the employees to perform specific jobs. Training helps in updating old talents and developing new ones. 'Successful candidates placed on the jobs need training to perform their duties effectively. According to Aswathappa, (2000) Effective training methods aimed at improving the employees' performance. 
Training not only develops the capabilities of the employee but sharpen their thinking ability and creativity in order to take better decision in time and in more productive manner David (2013).

Based on the above conceptual framework following alternative hypotheses have been advanced for the study.

a) The relationship between on- the- job training methods and performance of production assistants in Noritake Lanka Porcelain.

\section{Hypothesis 1}

$\mathrm{H}_{0}$ : There is no a significant relationship between on- the- job training methods and performance of production assistants in Noritake Lanka Porcelain.

$\mathrm{H}_{1}$ : There is a significant relationship between on- the- job training methods and performance of production assistants in Noritake Lanka Porcelain.

b) The impact of on- the- job training methods to performance of production assistants in Noritake Lanka Porcelain.

\section{Hypothesis 2}

$\mathrm{H}_{0}$ : There is no a significant impact of on- the- job training methods to performance of production assistants in Noritake Lanka Porcelain.

$\mathrm{H}_{1}$ : There is a significant impact on- the- job training methods to performance of production assistants in Noritake Lanka Porcelain.

\section{METHODOLOGY}

\subsection{Study Design}

This study is developed to assess the impact of on-the job training methods to the employees' performance in sector. Here the researcher will investigate the relationship between the training methods and employees' performance. The target population refers to the entire group of people, events or things of interest that the researcher wishes to investing. There are 1200 production assistants in Noritake Lanka Porcelain (Pvt). Accordingly, the target population of this study can be considered as the production assistants in Noritake Lanka Porcelain those who taken from selected departments. A production assistant's male or female who works in the Noritake Lanka Porcelain can be considered as sampling element and also the sample is chosen from temporary production assistants from selected departments. The data was collected through a structured questionnaire. 
Researcher will select $50 \%$ sample by using stratified random sampling techniques from population who receive on-the job training as follows.

Table 01: Sample Size

\begin{tabular}{|l|l|l|l|}
\hline \multicolumn{1}{|c|}{ Departments } & Number of employees & \multicolumn{1}{c|}{$\begin{array}{c}\text { Selected employees } \\
\mathbf{5 0 \%}\end{array}$} & Sample size \\
\hline Forming & 80 & 40 & 40 \\
\hline Preparation & 30 & 15 & 15 \\
\hline Molding & 24 & 12 & 12 \\
\hline Casting & 65 & 32.5 & 33 \\
\hline Total & $\mathbf{2 0 0}$ & & $\mathbf{1 0 0}$ \\
\hline
\end{tabular}

\subsection{Reliability and Validity}

The consistency reliability was examined with Cronbach's Alpha test. The results of Cronbach's alpha test are given in table 01, which suggests that the reliability of each variable is at a satisfactory level.

Table 02: Reliability Statistics of Variables

\begin{tabular}{|l|l|}
\hline \multicolumn{1}{|c|}{ Instrument } & \multicolumn{1}{c|}{ Cronbach's Alpha } \\
\hline Employee On-the job training & 0.893 \\
\hline Employee Performance & 0.872 \\
\hline
\end{tabular}

The construct validity of the variables of the study was ensured by the fact that the correlation and regression analysis support the hypotheses formulated linking the relationship between the independent variable and the dependent variable.

\subsection{Techniques of Data Analysis}

After gathering the data, it was analyzed by using the computer based statistical data analysis package, SPSS (version 23.0) for validity, reliability, Correlation and regression analysis were applied in data analysis to test the advanced hypotheses.

\subsection{Descriptive Statistics for The Independent Variable (Level of Performance)}

Table 03: Descriptive Statistic for Dependent Variable

\begin{tabular}{|c|c|c|}
\hline \multirow{2}{*}{$\mathrm{N}$} & Valid & 100 \\
\hline & Missing & 0 \\
\hline Mean & & 4.5600 \\
\hline Median & & 5.0000 \\
\hline Mode & & 5.00 \\
\hline Std. Deviation & & .55632 \\
\hline Variance & & .309 \\
\hline Skewness & & -.780 \\
\hline Std. Error of Skewness & & .241 \\
\hline Kurtosis & & -.436 \\
\hline Std. Error of Kurtosis & & .478 \\
\hline Minimum & & 3.00 \\
\hline
\end{tabular}




\begin{tabular}{|l|l|}
\hline Maximum & 5.00 \\
\hline Sum & 456.00 \\
\hline
\end{tabular}

According to Table 03 the researcher has entered 100 data points $(\mathrm{N}=100)$ and the most frequently selected choice was 5 (Mode=5), along with the midpoint of the distribution being resulted 5.0000 (Median=5.0000). Most importantly, according to the output table the average value of the total distribution for the independent variable (Mean=4.5600) is equal to 4.5600. Therefore, it can be interpreted as, the level of performance as measured on a five -point Likert scale, indicates that most of the respondents mostly agree with the level of Performance can be increased when increase the level of on-the job training. The Minimum of 3 indicates that there are some production assistants who perceived neither agree nor disagree that level of performance increases when increase the level of on-the job training. The Maximum of 5 indicates that some production assistants are strongly agreed that level of performance increases when increase the level of on-the job training.

\subsection{Relationship Between On-The-Job Training and Employee Performance}

Pearson's correlation was one of the tools used to test the hypothesis. For the hypothesis testing, desired level of significance was 0.05. These hypotheses tested by using correlation Analysis. This analysis results have shown as follows

Table 04: Correlation Between on the Job Training and Employees' Performance

\section{Correlations}

\begin{tabular}{|ll|l|l|}
\hline & & LONJR & LTP \\
\hline \multirow{4}{*}{ LONJR } & Pearson Correlation & 1 & $.764^{* *}$ \\
& Sig. (2-tailed) & & .000 \\
& $\mathrm{~N}$ & 100 & 100 \\
Pearson Correlation & $.764^{* *}$ & 1 \\
& Sig. (2-tailed) & .000 & \\
& $\mathrm{~N}$ & 100 & 100 \\
\hline
\end{tabular}

**. Correlation is significant at the 0.01 level (2-tailed).

Pearson's correlation is a tool used to test the hypothesis. The Pearson's correlation is used to find a correlation between at least two continuous variables. The values of the Pearson Correlation range from -1 to +1 with negative numbers representing a negative correlation (as one variable increases, the other variable decreases) and positive numbers representing a positive correlation (as one variable increases, the other also increases). The Pearson Correlation value for level of on-the-job training and level of employee performance was 0.764 and it was a positive relationship.

According to the Table 04 Pearson Correlation Coefficient between on-the-job training and performance was 0.764 . It indicates that there was strong positive relationship between these two 
variables. This found relationship was statistically significant, because sig value was 0.000 . It is standard that significant value should be less than 0.5563 , and then the correlation is considered to be significant. Therefore, it can be statistically indicating that there was a significant and strongly positive relationship between on-the-job training and performance. As there is no negative sign presented in front of the coefficient value it can be said that there is a positive correlation between the independent and dependent variable. Therefore, the higher level of employee performance is associated with a higher level the on the job training.

\subsection{Regression Analysis}

In this study, multiple regression analysis was used to provide pattern of relationship between the training programs and employee performance. To meet the objective of the study related model was developed. The model included only independent variable and one dependent variable. According to the regression analysis the relationship between level of on-the-job training and level of employee performance can be observed as follows.

Table 05: Model Summary

Model Summary

\begin{tabular}{|l|l|l|l|l|}
\hline Model & R & R Square & Adjusted R Square & Std. Error of the Estimate \\
\hline 1 & $.564^{\mathrm{a}}$ & .318 & .311 & .46189 \\
\hline
\end{tabular}

$\mathrm{R}^{2}$ (Coefficient) assumes that every independent variable in the model contributed to explain variation in the dependent variable. It meant the percentage of explained variation as if all independent variables the model effect the dependent variation. An $\mathrm{R}^{2}$ of 1 indicated that the regression line perfectly fits the data. According to the $\mathrm{R}^{2}$ and adjusted $\mathrm{R}^{2}$ values (Table 05 ) of 0.318 and 0.311 respectively both indicated that there was a moderate degree of goodness of fit of the regression model.

There is a positive relationship between levels of on-the-job training to the level of employee performance. According to the statistical data the regression coefficient of level of on-the-job training indicates that has a positive influence on level of employee performance. This contributes to the hypothesis (H1) of the study. The results had indicated that on-the-job training was the most important factor to consider as basically for the employee performance. Because the standardize coefficient of beta was 0.562 and significant value was $0.000(\mathrm{p}<0.05)$

Concerning this study, multiple regression analysis was used to provide pattern of performance. To meet the objective of the study one model was developed. The relationship between the set of predictors and the outcome factor (employee model included on-the-job training as independent variables and dependent variable employee performance) 
Table 06: ANOVA

ANOVA

\begin{tabular}{|ll|l|l|l|l|l|}
\hline Model & & Sum of Squares & Df & Mean Square & F & Sig. \\
\hline \multirow{4}{*}{1} & Regression & 9.732 & 1 & 9.732 & 45.619 & $.000^{\mathrm{b}}$ \\
& Residual & 20.908 & 98 & .213 & & \\
& Total & 30.640 & 99 & & & \\
\hline
\end{tabular}

a. Dependent Variable

b. Predictors: (Constant)

The regression sum of squares showed how much variability is accounted by the regression model, which is the fitting of the least-squares line. The total variability is the sum of both regression and residual variability $(20.908+9.732=30.64)$. The $\mathrm{F}$ test was 45.619 with the significance ('Sig') of 0.000 (Table 4.12). This explained that the probability of these results occurred by chance was less than 0.05 . So that a significant relationship was presented between level of on-the-job training and level of employee performance.

Table 07: Coefficient

\section{Coefficients}

\begin{tabular}{|ll|l|l|l|l|l|}
\hline \multirow{2}{*}{ Model } & \multicolumn{2}{|l|}{ Unstandardized Coefficients } & $\begin{array}{l}\text { Standardized } \\
\text { Coefficients }\end{array}$ & Sig. \\
\cline { 3 - 6 } & & B & Std. Error & Beta & & \\
\hline \multirow{2}{*}{1} & (Constant) & 1.837 & .406 & .564 & 4.528 & .000 \\
& LONJR & .579 & .086 & 6.754 & .000 \\
\hline
\end{tabular}

a. Dependent Variable

There is a positive relationship between level of on-the-job training and level of employee performance. According to the statistical data the regression coefficient of on-the-job training indicates that has a positive influence on employee performance. This contributes to the hypothesis (H1) of the study. The results had indicated that on-the-job training was the most important factor to consider as basically for the employee performance. Because the standardize coefficient of beta was 0.579 and significant value was $0.000(\mathrm{p}<0.05)$

Concerning this study, multiple regression analysis was used to provide pattern of performance. To meet the objective of the study one model was developed. The relationship between the set of predictors and the outcome factor (employee model included that level of on-the-job training as independent variables and one dependent variable (level of employee performance)

The regression analysis can also be used to determine the values of dependent variable given the values of one or more independent variables by calculating a multiple regression equation. As the part of research has obtained data on on-the-job training, to employee performance of Production assistants in Noritake Lanka Porcelain by using 100 people in Matale district. It has been represented as an equation: 


\section{Employee performance $=\alpha \dot{\alpha}+\beta 1$ on-the-job training}

The date has entered to the analysis and undertaken a multiple regression. And results substituted the understanding coefficient into regression equation:

EP $($ Employee performance $)=1.848+0.579($ On $)$

$\mathrm{EP}=$ Employee performance

On= On-the-job training

The positive relationship between on-the-job training was found to employee performance. The results had indicated on-the-job training was the most important factor to consider as basically for the employee performance. Because the standardize coefficient of beta was 0.579 and significant value was 0.000 ( $p$ $<0.05)$

\section{IMPLICATIONS}

The findings of the current research study will be important on the theoretically as well as the practically. The findings of the study are important to improve employees' performance of the nonexecutive workers in Noritake Lanka Porcelain (Pvt) Ltd in Matale District. Further this study will contribute to the organization in organizing their future training programs to factory workers. As the findings proves that there is a significance relationship in between on the job training method and employee performance, they can make decisions on the method of training should use on factory workers. Other than that this study finding are significant to manufacturing industry when designing their training programmes. Further the findings will add to the existing literature on researches regarding training and performance in Sri Lankan context.

\section{RECOMMENDATION}

The results of data analysis showed that on-the-job training has a significant impact on employee performance. Correlation analysis showed that on-the-job training influenced on employee performance has a strong positive correlation. This would mean that it is very significant to pay a high attention regarding the on-the-job training methods, because it directly affects to the performance of the employees in addition to that proper and well-structured on-the-job training are required to meet with the desired outcomes of the organization. A lot of benefits can be obtained from the on-the-job training method both employees and the organization.

It is very important to the managers of the Noritake Lanka Porcelain pvt Ltd to consider about the ways of using on-the-job training methods with the view of enhancing the knowledge, skills and attitudes of employees. On-the-job training methods are less costly than off-the-job training methods therefore the 
suitable on-the-job training methods have to be selected to train the employee should embrace on-thejob-training in order to enhance employee efficiency and performance and thus add profitability in the organization.

The organizations with proper laid down employee on-the-job-training programs will enhance employee performance and thus increase the levels of task performance. When considering the private manufacturing organization, it is better to use on-the-job training methods with the view enhance Production assistants' performance in proper manner.

\section{LIMITATIONS}

Therefore, future researches are needed to explore some of the issues not answered in this research. It is better to concern about the technological changes of the business environment. In present situation lot of manufacturing sectors convert their business activities in to automated system, so that it is better to pay attention about the technological changes happening in the manufacturing industry, because the on-the job training methods that are provided to the employees highly affected by the modern technological changes. And also it is important to consider about the culture of the organization.

\section{CONCLUSION}

The current study concludes declaring that on the job training is significantly associated with employee's performance.

This study however, clearly emphasizes the influence and importance of the training on the employees in the manufacturing sector that positively affected to the employees' performance. It can be assumed that those employees who have taken on-the job training were more capable in performing indifferent tasks in Noritake Lanka Porcelain pvt Ltd. Findings of the study can be utilized in designing the future training programs in Noritake Lanka Porcelain pvt Ltd as well as in other manufacturing companies. 


\section{REFERENCE}

Richard, R.,\& H.Aronson. (2012, December). Managing contexual performance. Retrieved from http://www.Researchgate net

Alipour and Mehrdad . (2009). A Study of on the Job Training Effectiveness: Empirical. International Journal of Business and Management, 65.

Alipour, M. (2009). A Study of on the Job Training Effectiveness: Empirical. International Journal of Business and Management, 65.

Alipour,B., and Mehrdad K. (2009). A Study of on the Job Training Effectiveness: Empirical. International Journal of Business and Management, 65.

Aslam, F. a. (2014). International journal of advance reseach in computer science and management studies, 632.

Aswathappa, K. (2000). Human Resource and Personal Management. New Delhi: Mcgraw-Hiill.

B. N., \& H. K. (2003). Valuing Task and Contextual Performance: Applied H.R.M. Research, 8, 17.

Befort, N., \& H. K. (2003). Valuing task and contexual performance: Experience, job roles and rating of the importance of job behaviour. Applied HRM research, 8, 1 .

David. (2013). The Effect of Training on Employee performance. Europian journal for business management, 139.

Elaine, D, \& Arad, S. (2008). Adaptive performance. Washington DC.

Elnaga, A. a. (2013). The Effect of Training on Employee Performance. European Journal of Business and Management, 05, 141.

Elnaga, A., \& A. (2013). The Effect of Training on Employee Performance. European Journal of Business and Management, 141.

Hamidun. (2003). The influence of training on employees's work commitment and performance.

Hamidun, H. b. (2003). The Influence of Training on Employee's.

HAN, C. (1988). he role of consumer patriotism in the choice of domestic versus foreign products. Journal of Advertising Research.

i. k., D. M., \& H. A. (2013). Effect Of Training Dimensions On Employee's Work. International Journal of Business and Management Invention, 2, 142.

Imran, D. .. (2013). The Effect of Training on Employee Performance. European Journal of Business and Management.

Jie, \& Roger. (2013). The Effect of Training on Employee performance. Eurpian journal for business management, 139.

Khan,F.,Raslia,A,M., , Rosman,M. (2014). Job rotation, job performance, Organizational commitment: an emperical study on bank empolyees Faisal. Journal of Management Info, 33-46.

Khan,Raslia,Rosman. (2014). Job rotation, job performance, Organizational commitment: an emperical study on bank empolyees Faisal. Journal of Management Info, 33-46. 
Klein, J., \& Ettenson, R. (1999). Consumer animosity and consumer ethnocentrism: an analysis of unique antecedents. . Journal of International Consumer Marketing.

Kogan. (2001). Hand book of Human Resource Management practice (8 ed.).

Mawita. (2000). Pakisthan Economic and social review. 269-292.

Ms. Pallavi P. Kulkarni. (2013). A Literature Review on Training \& . Journal of Arts, Science \& Commerce , 139.

Nassazi, A. (2013). Aidah Nassazi. Uganda.

Rao, P. S. (2009). “Essentials of Human Resource management and Industrial Relations. Himalaya Publication House.

Rowden , \& Conine. (2013). The Effect of Training on Employee performance. Europian journal for business management, 139.

sekaran, U. (2003). Research Methods for Business - Fourth Edition.

Sharma, S., Shimp, T., \& Shin, J. (1995). Consumer ethnocentrism: a test of antecedents and moderators. Journal of the Academy of Marketing Science.

Tarus,B,K. (2014). Effects of Job Rotation Strategy on High Performance Workplace, in. International Journal of Business and Management; Vol. 9, No. 11, 140.

Trang, D. N. (2014). Training Affects the Employee's Performance. Hcmc, Vietnam.

Yaqoob, Q. A. (2011). Impact of training and development on organizational performance. Global Journal of Management and Business Research Volume 11, 64. 